\title{
United States public policy and the elderly
}

\section{The disproportionate risk to the well-being of women*}

\author{
Richard V. Burkhauser ${ }^{1}$ and Greg J. Duncan ${ }^{2}$ \\ ${ }^{1}$ Syracuse University, 400 Maxwell Hall, Syracuse, NY 13244-1090, USA \\ ${ }^{2}$ University of Michigan, Institute for Social Research, Ann Arbor, MI 48109, USA
}

Received June 6, 1990 / Accepted February 13, 1991

\begin{abstract}
Cross-sectional comparisons show that poverty among the aged in the United States has dropped dramatically over the last two decades. We use longitudinal data to identify economic events associated with unfavorable economic outcomes and to trace the influence of these events on women and men at different ages. We find that while social insurance programs appear to prevent severe financial hardship from the most frequent work-related events, they are far less effective in cushioning the economic impact of widowhood and divorce, especially for women. We suggest a number of policy changes that would provide some measure of social insurance against adverse family-related events.
\end{abstract}

\section{Introduction}

A major goal of social insurance is to mitigate the risk of economic losses associated with income-threatening events. All modern industrialized countries have sophisticated government programs to reduce the financial uncertainty surrounding unemployment, retirement, and disability. In the United States, such programs have been successful in reducing the risk of a drop in economic well-being for most workers and their families (Burkhauser and Duncan 1989). But for women, risks to their well-being come increasingly from factors outside the labor market. And the United States social insurance system, developed primarily in the 1930s, is failing to shield them from dramatic drops in economic well-being associated with these non-market factors.

\footnotetext{
* This paper was presented at the ISPE Conference on the Fiscal Implications of an Aging Population, Limburg, The Netherlands, May 30, 1990. The authors shared equally in writing the paper and are listed alphabetically. The paper was completed while R.V. Burkhauser was a fellow at The Netherlands Institute for Advanced Studies in the Humanities and Social Sciences. Deborah Laren provided superb research assistance.
}

Offprint requests to: R.V. Burkhauser 
The United States social insurance system is based on income replacement for work-related income-threatening events. Unemployment insurance is provided only for those with adequate work histories. (See Hanson and Byers 1990, for a history of United States unemployment insurance programs.) It offers no protection to those either entering the labor force for the first time or reentering after years of non-market activities. Social Security Old-Age retirement benefits are based on previous wage earnings and provide no direct benefits to those who work outside the market. (See Quinn et al. 1990, for a discussion of the US Social Security retirement system.) The same is true of Social Security disability insurance. One must have a recent work history to be eligible for benefits and those benefits are based on past earnings. (See Burkhauser and Haveman 1982 for a discussion of the US Social Security disability system.)

These pillars of United States social insurance were developed in a time when most men worked outside the home and their wives stayed home and raised the children; hence, all family members would be protected by replacing the income of the principal breadwinner. No provision was made in unemployment insurance for women who reentered the work force after a period of child-rearing. Social Security benefit rules severely penalize households with two earners and provide no protection for those disabled women who were out of the labor market for a number of years prior to onset of their disabling condition. (See Burkhauser and Holden 1982, for a fuller dicussion of these points.)

In a world where the typical family had one breadwinner and women generally withdrew permanently from the work force following marriage, or at least after childbirth, no provisions for secondary earners were deemed necessary. In such a world, it was convenient to provide women who did not work in the market with benefits based on their husband's earnings. Thus, a spouse benefit in retirement or a survivor or mother's benefit following a worker's death is based on the worker's earning record. The same is true of disability benefits for mothers and children. Such a payment system would appear reasonable in a world where marriages lasted forever and only one worker per family was the rule.

But today in the United States, even women who marry are likely to spend a considerable portion of their lives alone, first because marriages are more likely to end in divorce than with the death of a spouse, and second because the growing life expectancy of women relative to men is extending the period over which women whose marriages do not end in divorce will live as widows. These demographic factors make it imperative to reexamine the success of our social insurance and social welfare system in coping with the risks to the economic wellbeing of women posed by life without, or after, marriage.

In this article we document the dramatic success of American policy over the past two decades in mitigating the risk of drops in economic well-being at older ages, but point out that this success has been far from uniform. We show that women today face disproportionate economic risks throughout their lives and especially in old age. Furthermore, the gender gap in well-being at older ages has, if anything, increased over the past two decades.

We then move beyond the usual snapshot view of economic well-being captured by cross-sectional analysis and look at how women and men fare as they experience economic hardship related to the marketplace and/or marital dissolution. We show that the disproportionate risks to women captured by cross-sectional data are even more serious when viewed from a longitudinal perspective, since women spend longer than men recovering from economic difficulties. 


\section{The relative economic deprivation of women}

The chance of falling into poverty later in life has dropped dramatically in the United States over the past three decades. As can be seen in Table 1, poverty rates for those aged 65 years and over in 1959 were more than twice those of younger people. (See Appendix for a discussion of the source of the table.) The War on Poverty and the increasing percentage of older people eligible to receive Social Security retirement benefits lead to substantial improvements in the poverty rates of young and old alike in the 1960s. Hence, by the end of the decade, while the poverty rate of older people had fallen considerably, those over age 65 were still more than twice as likely to be poor as younger people.

But this disproportionate risk of poverty at older ages dropped dramatically in the 1970s. Major increases in Social Security benefits in the early part of the decade as well as the federalization of state old-age welfare systems through the Supplemental Security Income Program further reduced the poverty rate of older people. Over this same period, the poverty rates of people under 65 drifted upward, so that old-age poverty was only $29 \%$ higher than that of younger people by 1975 . During the recession years of the early 1980 s the poverty rates of younger people continued to climb while poverty rates of older people continued to decline; by 1985 the average older person was less likely to be poor than the average younger person. In 1987, poverty rates of older people were $12.2 \%$, or $89 \%$ of the rate of younger persons.

While the risk of poverty for both older women and men has fallen substantially over the past three decades, the relative disparity between women and men has actually grown. In 1959, the poverty rate of older women was only about $20 \%$ higher than that of older men. This was approximately the same difference found between the poverty rates of younger women and men. While older women's poverty rates fell from $40.0 \%$ to $14.9 \%$ over the next three decades, the poverty rate of older men fell even more, from $33.1 \%$ to $8.5 \%$. Hence, by 1987 older women were $75 \%$ more likely to be in poverty than men. In contrast, the dif-

Table 1. Relative poverty status of women $1959-1987$

\begin{tabular}{|c|c|c|c|c|c|c|c|c|c|c|}
\hline \multirow[t]{2}{*}{ Year } & \multicolumn{4}{|c|}{ Under age 65 years } & \multicolumn{4}{|c|}{65 years and older } & \multirow[b]{2}{*}{$\begin{array}{l}\text { Age } \\
\text { ratio } \\
(5 / 1)\end{array}$} & \multirow[b]{2}{*}{$\begin{array}{l}\text { Overal } \\
\text { poverty } \\
\text { rate }\end{array}$} \\
\hline & $\begin{array}{l}\text { Both } \\
\text { sexes } \\
(1)\end{array}$ & $\begin{array}{l}\text { Women } \\
\text { (2) }\end{array}$ & $\begin{array}{l}\text { Men } \\
\text { (3) }\end{array}$ & $\begin{array}{l}\text { Sex } \\
\text { ratio } \\
(2 / 3)\end{array}$ & $\begin{array}{l}\text { Both } \\
\text { sexes } \\
(5)\end{array}$ & $\begin{array}{l}\text { Women } \\
\text { (6) }\end{array}$ & $\begin{array}{l}\text { Men } \\
(7)\end{array}$ & $\begin{array}{l}\text { Sex } \\
\text { ratio } \\
(6 / 7)\end{array}$ & & \\
\hline 1959 & $16.1^{\mathrm{a}}$ & $17.9^{\mathrm{a}}$ & $14.2^{\mathrm{a}}$ & 1.26 & 36.9 & 40.0 & 33.1 & 1.21 & 2.29 & 18.2 \\
\hline 1969 & 10.8 & 11.8 & 9.7 & 1.22 & 25.3 & 29.2 & 20.2 & 1.45 & 2.34 & 12.2 \\
\hline 1970 & 11.3 & 12.3 & 10.4 & 1.18 & 24.6 & 28.5 & 19.0 & 1.50 & 2.18 & 12.6 \\
\hline 1971 & 11.5 & 12.7 & 10.4 & 1.22 & 21.6 & 25.8 & 15.6 & 1.65 & 1.88 & 12.5 \\
\hline 1975 & 11.9 & 13.2 & 10.6 & 1.25 & 15.3 & 18.1 & 11.4 & 1.59 & 1.29 & 12.3 \\
\hline 1980 & 12.7 & 14.1 & 11.2 & 1.26 & 15.7 & 18.9 & 10.9 & 1.73 & 1.24 & 13.0 \\
\hline 1985 & 14.1 & 15.6 & 12.7 & 1.23 & 12.6 & 15.6 & 8.5 & 1.84 & 0.89 & 14.0 \\
\hline 1987 & 13.7 & 15.0 & 12.4 & 1.20 & 12.2 & 14.9 & 8.5 & 1.75 & 0.89 & 13.5 \\
\hline
\end{tabular}

Data from 1959 from Ross (1986), all other data derived from US Department of Commerce, P-60 Series (various years)

${ }^{a}$ People aged 25 to 64 years 
Table 2. Poverty status of older women (Aged 65 years and over) distributed by marital states $1971-1987$

\begin{tabular}{llllll}
\hline Year & \multicolumn{2}{l}{ Marital status } & & & \\
\cline { 2 - 6 } & Married & Widowed & Divorced & Single & Total \\
\hline 1971 & 11.7 & 35.1 & 37.3 & 21.4 & 25.8 \\
1975 & 8.0 & 23.4 & 32.1 & 21.7 & 18.1 \\
1980 & 8.1 & 25.1 & 39.5 & 22.7 & 18.9 \\
1985 & 5.4 & 23.1 & 29.4 & 18.8 & 15.6 \\
1987 & 5.7 & 20.0 & 26.9 & 23.3 & 14.9 \\
\hline
\end{tabular}

Derived from US Department of Commerce, P-60 Series (various years)

ference in poverty rates of younger women and men has remained about the same over the past three decades.

With the exception of never-married women, the incidence of poverty among older women, regardless of marital status, has fallen since 1971. But as can be seen in Table 2 the difference in poverty rates between married and unmarried older women has grown. In 1971 older married women had a poverty rate of $11.7 \%$; by 1987 it had fallen to $5.7 \%$. Older widows were three times as likely to be in poverty as older married women in 1971. Even though the poverty rate of older widows fell substantially over the period, by 1987 they were three and onehalf times as likely to be in poverty as older married women. Older divorced women were also about three times as likely to be in poverty as older married women in 1971, and by 1987 they were five times as likely. Hence, even as poverty among older women as a whole has declined over time, marital status has become an increasingly important predictor of low income status.

The importance of marital status in accounting for the incidence of poverty in 1987 among women and men at different ages is illustrated vividly in Table 3. The United States social welfare system has done a remarkably good job of insuring married women and married men against poverty. Poverty rates of married women vary modestly between $4.8 \%$ and $6.6 \%$ across all ages and are approximately the same as those of married men. (They are not identical because spouses are not always within the same age range).

But the same cannot be said for unmarried women, especially older unmarried women. Not only are poverty rates of such women higher than those of older unmarried men, but a much greater share of older women are widowed or divorced. Only $40 \%$ of women aged 65 or over are married and living with their husbands. By contrast, $75 \%$ of all older men are living with a spouse. It is this widening gap in economic well-being between women and men and between the married and unmarried that constitutes the unfinished business of social policy toward the aged in the United States.

Cross-sectional snapshot data leave unanswered many important questions about how social policy affects the economic status of individuals as they age. For example, the fact that widowed or divorced women have so much higher rates of poverty than either men or married women is consistent with two very different explanations. First, the divorce or widowhood event itself many have a dramatic effect on economic status, with social policy doing little to cushion the losses. 
Table 3. Poverty status in 1987 of persons distributed by age and marital status ${ }^{\text {a }}$

\begin{tabular}{|c|c|c|c|c|c|}
\hline \multirow[t]{2}{*}{ Marital status } & \multicolumn{2}{|l|}{ Females } & \multicolumn{2}{|l|}{ Males } & \multirow{2}{*}{$\begin{array}{l}\text { Ratio of female } \\
\text { poverty rate to } \\
\text { male poverty rate }\end{array}$} \\
\hline & $\begin{array}{l}\text { Share of } \\
\text { population. }\end{array}$ & $\begin{array}{l}\text { Percent in } \\
\text { poverty }\end{array}$ & $\begin{array}{l}\text { Share of } \\
\text { population }\end{array}$ & $\begin{array}{l}\text { Percent below } \\
\text { poverty }\end{array}$ & \\
\hline 65 years and over & 100 & 14.9 & 100 & 8.5 & 1.75 \\
\hline Single & 5 & 23.3 & 5 & 17.7 & 1.32 \\
\hline Married & 40 & 5.7 & 75 & 5.9 & 0.97 \\
\hline Widowed & 49 & 20.0 & 14 & 14.6 & 1.37 \\
\hline Divorced $^{b}$ & 6 & 23.9 & 6 & 19.1 & 1.25 \\
\hline 55 to 64 years & 100 & 11.6 & 100 & 8.8 & 1.32 \\
\hline Single & 4 & 16.7 & 5 & 23.3 & 0.72 \\
\hline Married & 67 & 5.4 & 81 & 6.1 & 0.89 \\
\hline Widowed & 17 & 25.1 & 4 & 16.6 & 1.51 \\
\hline Divorced $^{b}$ & 12 & 21.2 & 10 & 18.5 & 1.15 \\
\hline 45 to 54 years & 100 & 9.4 & 100 & 6.6 & 1.42 \\
\hline Single & 5 & 17.5 & 6 & 19.1 & 0.92 \\
\hline Married & 71 & 4.8 & 79 & 4.5 & 1.07 \\
\hline Widowed & 6 & 23.8 & 1 & 22.9 & 1.04 \\
\hline Divorced $^{b}$ & 18 & 17.4 & 14 & 11.1 & 1.57 \\
\hline 15 to 44 years & 100 & 14.1 & 100 & 9.8 & 1.44 \\
\hline Single & 35 & 18.7 & 45 & 12.5 & 1.50 \\
\hline Married & 51 & 6.6 & 46 & 6.5 & 1.02 \\
\hline Widowed & 1 & 28.6 & 0 & 12.1 & 2.36 \\
\hline Divorced $^{b}$ & 13 & 23.5 & 9 & 11.3 & 2.08 \\
\hline 15 years and over & - & 13.4 & - & 9.1 & 1.47 \\
\hline
\end{tabular}

Derived from US Department of Commerce, P-60 Series (1989), Table 8

${ }^{a}$ Marital status is as of May 1988. Income is for 1987. This will understate household income of those widowed or divorced women who change marital status during 1987 or 1988 (see Burkhauser et al. 1986)

${ }^{\mathrm{b}}$ Includes those who are married but whose spouse is absent

A second, very different explanation posits that events such as divorce or widowhood are highly selective, occurring much more frequently among couples near or below the poverty line prior to the event. Social policy may be doing an excellent job of minimizing the economic consequences of income-threatening events, but the selective nature of the events could create in cross-sectional data the appearance of a failed social policy.

A more reliable picture of the dynamics of economic well-being in an aging population requires information on the risks of income-threatening events at different life-cycle stages, direct measurement of pre- vs. post-event changes in living standards that surround such events, and evidence on the duration of economic deprivation associated with such events. These are provided in the next section.

\section{A multi-period view of economic well-being}

The empirical results that follow are based on data from the Panel Study of Income Dynamics (PSID) and cover the period from 1968 to 1986. Beginning in 
1968 , the year of its first interviews, the PSID provides longitudinal economic and demographic information on a representative sample of the United States (see the appendix).

Our measure of economic status is size-adjusted total family money income, obtained by summing all sources of income (including social security transfers) for all family members during a calendar year and dividing that income total by the United States federal government's annually calculated poverty thresholds for families with different compositions based on the number, sex, and age of family members. As others before us, we will term the resulting measure the incometo-needs ratio. The poverty threshold for a family of four in 1988 dollars was approximately $\$ 12000$. The threshold for an elderly person living alone was about $\$ 5700$. A family of four with an income of $\$ 36000$ would have an incometo-needs ratio of 3.0. An elderly women living by herself with an income of $\$ 2850$ would be deemed poor, with an income-to-needs ratio of 0.5 .

Most longitudinal studies of the economic well-being of the aged have looked at poverty transitions (Campbell and Hudson 1985; Zick and Smith 1986; Burkhauser et al. 1988; Coe 1988). However, a fall into poverty can often be gradual, and may, in the end, result from only a very small (in the extreme, one dollar) drop in income. Thus, while poverty transitions are important in estimating absolute deprivation, they are inadequate for measuring dramatic drops in economic well-being.

A more complete look at changes in economic well-being can be based on relative changes in the income-to-needs ratio. For example, we describe the relative economic impact of labor market and family-related events on the men and women who experience them by looking at income-to-needs levels before and after the events occur. We also attempt to isolate both a dramatic income fall and an element of absolute deprivation by identifying instances in which the incometo-needs ratio fell by $50 \%$ or more, and the final level of the income-to-needs ratio was 1.5 or below.

Official poverty thresholds consider the family to be the appropriate unit for the measurement of economic status. Individuals within families are assumed to share resources equally. We share this assumption, presuming that all members of a family share in total income during the period when they are together. Our choice of unit of analysis depends on the event we are analyzing. For our analysis of labor-market events - unemployment, retirement and disability - we use intact married-couple households as the analysis unit.

In our analysis of family events - widowhood and divorce - we use individual men and women as units of analysis. By following individuals, we are in a position to show that the risks to well-being associated with various lifecourse events, and the role of public policy in coping with these risk, are very different for women and men.

\section{Incidence of events and their short-run economic consequences}

Social policy in the United States has long attempted to prevent dramatic drops in economic well-being associated with disruptions of market work. In this section we will use longitudinal data from the PSID to estimate the incidence of these events and then determine how often these events produce dramatic drops in post-transfer economic well-being. Because we are interested in tracing the 
disparity between the economic well-being of women and men, we will also look at the consequences of marital dissolution (both divorce and widowhood) and contrast the economic outcomes of these family-based events, presumably less cushioned by social insurance, with those of events associated with the labor market.

Table 4 shows the incidence of the family- and labor market-based events we focus on, the precise definitions of which are presented in an appendix. Serious bouts of unemployment (totalling at least two months in a calendar year) are found to be the most common of the events shown in Table 4 for people under 50 , affecting about $5 \%$ of the husbands each year. At a rate of $8.25 \%$ per year, retirement is the most likely event for older couples. Not surprisingly, the death of a spouse is a more likely event for women than men.

To assess the economic consequences of these events, we examined incometo-needs ratios before and after the events occurred. Using events as the sample, Table 5 presents information on several measures of income-to-needs change surrounding each event: i) the median income-to-needs change among people experiencing the event; ii) whether income-to-needs was lower after the event than before; and iii) whether income-to-needs fell by more than $50 \%$ and to a point within $150 \%$ of the poverty line.

Despite unemployment insurance, serious unemployment is still associated with drops in economic well-being. As can be seen in Table 5, the median change in income-to-needs ratios of households in which an older husband is unemployed for at least two months is a fall of $14.8 \%$. Over $60 \%$ of older households experiencing unemployment suffer decreases in their relative economic well-being, and 5\% both suffer a fall of at least $50 \%$ in incometo-needs and have a post-event income of less than $150 \%$ of the poverty line. Households of younger husbands who experience unemployment are even worse off and are twice as likely to suffer dramatic drops in economic well-being.

Despite large increases in Social Security retirement benefits over the 1970s, retirement is still not without risks to economic well-being. The median change in income-to-needs is a drop of about $30 \%$ and nearly 5\% of retirees suffer dramatic drops in their standard of living.

In the United States, Social Security Disability Insurance offers far narrower protection than do most European systems, providing benefits only to those unable to perform any work. Benefits are not provided for partial disability. (See Haveman et al. 1984 and Burkhauser and Hirvonen 1989, for cross-national comparisons of Unites States and European disability systems). Accordingly, it is not surprising that disability presents a substantial risk of a dramatic, povertythreatening drop in economic well-being. About one-sixth of those who reduce their work because of a disability experience such a drop. Fortunately, disability is extremely rare, occurring to only about one-in-a-thousand younger husbands in a year (Table 4).

None of these work-related dangers is as devastating to the economic well-being of women as the dissolution of her household. Divorce at older ages is five times as likely to lead to a sharp decrease in living standards as retirement. Divorce at younger ages is equally devastating to women. Nearly one in five divorcing women suffers a dramatic drop in economic well-being. For both younger and older women the risks to economic well-being associated with divorce are far greater than those facing divorced men. (Burkhauser et al. 1990, find similar results for the Federal Republic of Germany.) 


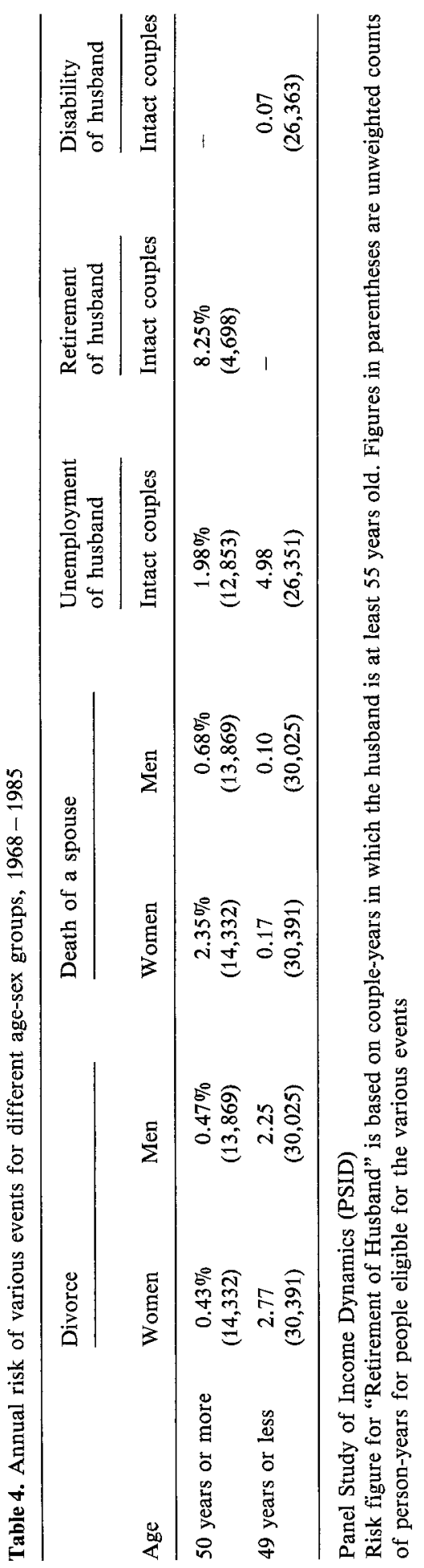




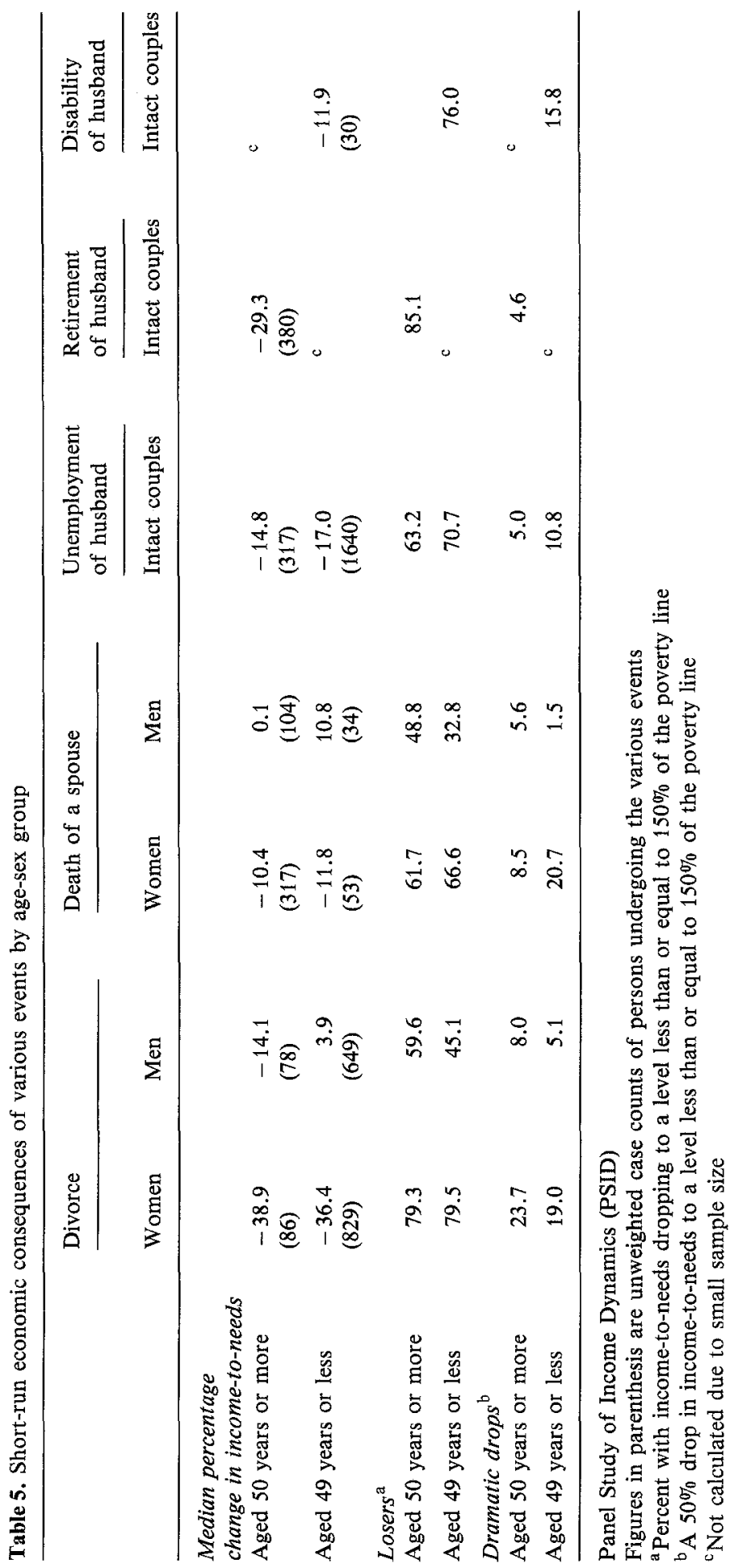


This same disproportionate impact for women is also observed following the death of a spouse. The median change in income-to-needs following the death of a spouse is actually positive for men (undoubtedly resulting more from a decrease in family size than an increase in income), while the median change for women is around minus $10 \%$. Death of a spouse is the event that holds the most serious risk of a dramatic drop in well-being for younger women. For older women the risk of financial hardship is much lower, but still greater than that of men.

\section{Longer-run consequences}

Focusing on the year after the events occur, Table 5 shows short-run changes in economic well-being associated with the five events. Since the duration of an income loss is arguably as important is its initial magnitude, we provide, in Table 6, information on how long it takes for income-to-needs ratios to recover to their pre-event levels. Entries in the table track individuals experiencing the events and show the fraction of affected individuals whose income-to-needs ratio has recovered to at least their pre-event level in the first, second, third, etc. year following the event. Since the first-year figures show the fraction of individuals with higher income-to-needs just after as compared with just before the event, they are the complement of the "Losers" row in Table 5. Figures for the second and subsequent years are based on life-table methods that handle observations censored by survey nonresponse or the end of the panel period.

We find that in the case of unemployment, for instance, only $29 \%$ of younger couples and $37 \%$ of older couples reporting severe unemployment had in the year in which the unemployment occurred income-to-needs equal to or greater than income-to-needs in the year before the unemployment. In the year following the severe unemployment (Year 2 on Table 6), $45 \%$ of the younger couples and $50 \%$ of the older ones had returned to pre-event income-to-needs levels; at the end of five years 68 and $66 \%$, respectively, had recovered. The median younger couple with severe unemployment took three years to recover; the median older couple took 2 years.

Table 5 showed that retirement-induced income losses were pervasive, although it was rare to find very large losses, to near or below the poverty line. Table 6 shows that full recovery of pre-retirement living standards is also quite unlikely. After five years only about $30 \%$ of retiring couples had returned to preretirement income levels. This is not so surprising, since for most males retirement means a permanent withdrawal from the labor force.

As with the short-term losses in Table 5, it is instructive to examine in Table 6 the relative outcomes of women and men following a divorce. For men, recovery is relatively rapid. The median divorced male under age 50 has fully recovered his standard of living after one year and $81 \%$ have recovered after 5 years. For older men recovery is slower and less sure. It takes three years for the median older male to recover, and only about three in five have recovered after 5 years.

For women, however, the long-run results of divorce are far more devastating. Not only are women substantially more likely to suffer a dramatic drop in economic well-being (Table 5), but among younger women recovery is far slower and less certain. Only $20 \%$ have recovered after one year; the median recovery period is 5 years. Among older women the recovery period is somewhat faster and more closely resembles that of older men. 


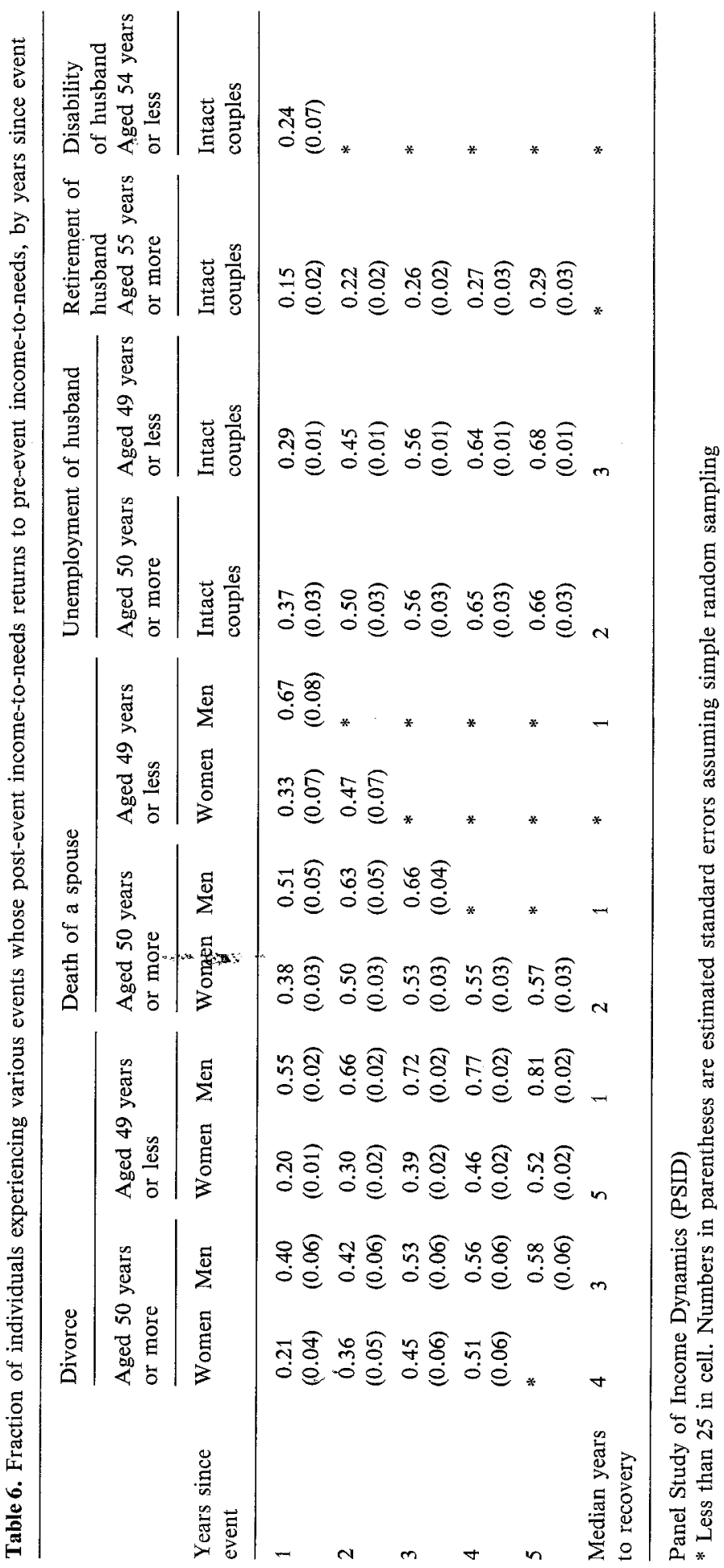


Unfortunately, our sample sizes are insufficient for comparing the incometo-needs path of younger widows and widowers. However, it is clear that widowers begin to recover much more quickly than widows. Two-thirds of widowers recover after one year, while only one in three widows do. Older widowers also recover more quickly than older widows but the difference is not quite as large as between younger men and women.

\section{Summary}

Cross-sectional comparisons show that poverty among the aged in the United States has dropped dramatically over the last two decades. Today older people are no more likely to be poor than younger people. But women of all ages have a higher risk of poverty than do men, and this disparity is highest at older ages. Cross-sectional data also show that this disparity in well-being can be traced primarily to the facts that non-married people have higher poverty rates than married people and that older women are much more likely to be non-married.

Here were have used multiperiod data from the PSID to identify economic events associated with unfavorable economic outcomes and to trace the influence of these events on women and men at different ages. Our data lead to the following characterizations of work-related events: Although retirement almost always brings with it a long-term drop in income-to-needs, few retiring couples suffer large, poverty-threatening declines in economic well-being. Social security retirement transfers undoubtedly figure prominently in preventing financial hardship. Substantial unemployment for husbands in married-couple families is considerably more frequent at younger than older ages. It usually produces a modest and fairly short-term decline in economic well-being. Permanent disability for husbands in married-couple families is exceedingly rare and produces losses similar in magnitude to unemployment. All in all, social insurance programs appear to prevent severe financial hardship from the most frequent work-related events.

The picture for family-related events is different, especially for women: Regardless of its timing, divorce typically produces sharp and long-lived economic hardship for women. The degree of loss easily exceeds that associated with retirement, unemployment and disability. In contrast, divorce has little impact on the living standards of men. The economic impact of widowhood is also much greater for surviving women than men. Although the typical widow does not suffer as large a drop in income-to-needs as the typical divorced women, comparable fractions (roughly one in five) do suffer large, poverty-threatening losses.

Part of the explanation for this disproportionate risk to women must be laid at the door of a public policy that has been slow to adjust social insurance and social welfare programs to offset the heightened economic risk facing women outside of marriage. Title IV of the Social Security Act of 1935 established the federal-state program for aid to dependent children and authorized payment from general revenues for the federal share of program costs. This program recognized to some extent the economic risks associated with a marital break-up, but limited the protection it offered to the parties of marital split - or to nonmarried parents whose separation might potentially harm the child. Hence, it was left to the civil courts to determine the losses to partners if a relationship without children dissolved or if one with children dissolved but did not drop the child below some 
minimum standard of living. Recent attempts to strengthen child support laws have helped somewhat, but much remains to be done.

A policy change that would greatly reduce the likelihood that newly-divorced mothers suffer dramatic drops in well-being is to expand to the national level experimental divorce laws in Wisconsin that guarantee the payment of child support. In Wisconsin, court-imposed child support payments are made directly by the State and it is then the responsibility of the State to collect them from the father. Payments equal a percentage of the father's earnings and if that amount falls below some guaranteed minimum, State funds are used to supplement those payments.

Current Social Security benefit rules substantially disadvantage homemakers who divorce, since the worker retains the right to the primary benefit after divorce while the spouse is entitled only to the spouse benefit; even this right is limited to a spouse who has been married for 10 years. Hence, for example, a worker eligible to receive $\$ 1000$ per month in Social Security benefits whose spouse has no earnings record would receive the $\$ 1000$ following divorce, while the spouse would receive only $\$ 500$. Spouses with their own history of earnings would receive the higher of $\$ 500$ or their own worker benefit based on this record. This system is, on paper, sex neutral. In reality, since most men have higher earnings than their wives when divorce occurs, the man is more likely to be the primary worker and hence to be entitled to the lager benefit. Older women who divorce are subject not only to the short-run problem of finding outside income to replace the earnings of their husbands, but - unless other assets are divided to reflect the unequal splitting of Social Security wealth - are also subject to the long-term consequences of a substantially diminished Social Security benefit.

This situation could be reversed if social security benefits were treated like private pension benefits. Community property laws in most States recognize that marriage is a partnership and that all assets earned in that marriage are equally divided in the case of divorce. "Earnings sharing", which assigns one-half of the total household wage earnings to each spouse for purposes of determining subsequent social security benefits would effectively create two equal benefits for married couples and hence offer more protection for divorced women.

A major advantage of longitudinal data is that they make possible a multiperiod view of the economic consequences of unfavorable economic events. Here we have shown that women need a longer time to recover following divorce or the death of a spouse. This underscores the need to begin to change social policy in order to mitigate the risk to economic well-being stemming from marital dissolution.

\section{Appendix}

Poverty as used throughout this paper is defined by the absolute standard embedded in the United States government poverty thresholds. These poverty lines were not officially set in the United States until 1965. Data for 1959 comes from Ross (1986) who adjusted the 1965 poverty line to 1959 Census data using the Consumer Price Index. She did this for those aged 25 to 64 and those 65 and over. All other years shown in Table 1 are derived from US Census Bureau's Current Population Survey data.

Although the federal government poverty thresholds were based originally on a food needs standard that incorporates many adjustments for differing family 
composition, the official thresholds do not use the detailed gradations. The poverty thresholds used in the PSID analysis incorporate the full detail, as well as the adjustments for part-year membership of family members. Other possible adjustments to family income include the valuation of in-kind benefits (including work-related in-kind fringe benefits), taxes paid, ownership of durables, resource allocation within families, amount of leisure time available, and work-related expenses. Danziger et al. (1984) estimated the importance of adjustments to cash income for taxes paid, durables, family size and composition, and the use of the individual rather than the household as the unit of analysis. They found that the family size and composition adjustments are by far the most important.

PSID data are taken from the cross-year 1986 response-nonresponse file of the Panel Study of Income Dynamics. Since 1968 the PSID has interviewed annually a representative sample of some five thousand families. At least one member of each family was either part of the original families interviewed in 1968 or born to a member of one of these families. Partial information on individuals who ceased to be respondents prior to 1986 is included in our analysis whenever possible. All data are weighted by the most recent individual weight for the particular statistic being estimated. The weights incorporate adjustments for differential selection probabilities as well as differential nonresponse. Extensive analyses of nonresponse cases have shown that they do not appear not to impart appreciable bias to the data (Becketti et al. 1983; Duncan et al. 1984). For a more complete discussion of these data, see Survey Research Center (1986).

Events are defined over three calendar years $(t, t+1$, and $t+2)$. Labor market events are typically based on a comparison of $t$ and $t+2$. Family composition changes are typically defined during the middle year $(t+1)$ in order to avoid confounding the income amounts with the family changes themselves. The definitions are as follows:

Income/needs change - Defined from a comparison of income/needs in calendar year $t$ and year $t+2$, for $t=1968-1982$. Income/needs is constructed as the ratio of the family's total money income to the poverty threshold for a family of the given size and composition. The two-year interval is necessary since familybased changes produce ambiguous income data in the year of the change.

Divorce - A change from living with a spouse or permanent partner in year $t$ to not living with that same spouse or partner due to divorce or separation in year $t+1$. This transition is defined only for heads of households and wives.

Widowhood - A change from living with a spouse or permanent partner in year $t$ to not living with that same spouse or partner due to his or her death in year $t+1$. This transition is defined only for heads of households and wives.

Major unemployment - A change in the head's workdays lost due to unemployment from less than two months in calendar year $t$ to more than two months in year $t+2$. (For 1968-1974, work lost due to strikes is included with that lost due to unemployment.) This transition is defined only for couples who remain living together.

Retirement - A change in the head's reported employment status from not retired to retired, accompanied by a change in his annual hours worked from more 
than 1000 in calendar year $t$ to less than 500 in year $t+2$. This transition is defined only for couples who remain living together and for whom the head is age 55 or older.

Disability - A change in the head's assessment of the extent to which his work is limited by disability, from a small amount (or not at all) to a large degree, accompanied by a change in his annual hours worked from more than 1000 in calendar year $t$ to less than 500 in year $t+2$. Head's reported employment status also changes from not disabled to disabled. (In the interviews 1969-1975, employment status did not distinguish retired and disabled.) This transition is defined only for couples who remain living together and for whom the head is under age 50.

\section{References}

Becketti S, Gould W, Lillard L, Welch F (1983) Attrition from the PSID. (Mimeo) Unicon Research Corp, Los Angeles

Burkhauser RV, Duncan GJ (1989) Economic risks of gender roles: income loss and life events over the life courses. Soc Sci Q 70 (3):3-23

Burkhauser RV, Haveman RH (1982) Disability and work: The economics of American policy. The Johns Hopkins University Press, Baltimore

Burkhauser RV, Hiroven P (1989) United States disability policy in a time of economic crisis: A comparison with Sweden and the Federal Republic of Germany. Milbank Quarterly 67 (Suppl 2): $166-194$

Burkhauser RV, Holden KC (eds) (1982) A challenge to Social Security: The changing roles of women and men in American society. Academic Press, New York

Burkhauser RV, Holden KC, Myers DA (1986) The role of survey procedures in artificially creating poverty. Demography 23:621-631

Burkhauser RV, Holden KC, Feaster JC (1988) Incidence, timing and events associated with poverty: A dynamic view of poverty in retirement. J Gerontol 43(2):S46-S52

Burkhauser RV, Duncan GJ, Hauser R, Berntsen R (1990) Economic burdens of marital disruptions: A comparison of the United States and the Federal Republic of Germany. The Review of Income and Wealth, Series 36, No. 4:319-333

Campbell R, Hudson C (1985) Synthetic cohorts from panel studies: An approch to studying rare events. Res Aging 7:81-93

Coe R (1988) A longitudinal examination of poverty in the elderly years. Gerontologist 28(4):540-544

Danziger S, van der Gaag J, Smolensky E, Taussig MK (1984) Implications of the relative economic status of the elderly for tranfer policy. In: Aaron $\mathrm{H}$, Burtless $\mathrm{G}$ (eds) Retirement and economic behavior. Brookings Institution, Washington DC, pp 175-196

Duncan GJ, Hill DH, Ponza MJ (1984) How representative is the PSID? A response to some questions raised in the Unicon report. (Mimeo) Institute for Social Research, Ann Arbor, Mich

Hansen WL, Byers JF (1990) Unemployment insurance: The second half-century. University of Wisconsin Press, Madison, WI

Havemann RH, Halberstadt V, Burkhauser RV (1984) Public policy toward disabled workers: A crossnational analysis of economic impact. Cornell University Press, Ithaca

Quinn JF, Burkhauser RV, Myers DA (1990) Passing the torch: The influence of economic incentives on work and retirement. UpJohn Institute for Employment Research, Kalamazoo, MI

Ross CM (1986) The change in the labor supply and well-being of the elderly, 1940-1980. PhD dissertation, University of Wisconsin

Survey Research Center (1984) User guide to the panel study of income dynamics. ICPSR Ann Arbor, MI

US Department of Commerce, Bureau of the Census. Various years Characteristics of the population below the poverty level. Current Population Reports, ser P-60. US Government Printing Office, Washington, DC

Zick CD, Smith KR (1986) Immediate and delayed effects of widowhood on poverty: Patterns from the 1970s. Gerontologist 26:669-676 